\title{
Identifikasi Respon Tanah terhadap Gelombang Gempa Bumi di Curup dan Implementasi Pembelajaran Fisika
}

\author{
Pio Kurnia Gusti ${ }^{1,2}$, Muhammad Farid ${ }^{3}$, Eko Swistoro ${ }^{1}$, Irwan Koto ${ }^{1}$ \\ ${ }^{1}$ Pascasarjana Pendidikan IPA FKIP Universitas Bengkulu \\ ${ }^{2}$ SMP Negeri 19 Rejang Lebong, Bengkulu \\ ${ }^{3}$ Jurusan Fisika FMIPA Universitas Bengkulu \\ *Email: piokurniagusti@gmail.com
}

DOI: https://doi.org/10.33369/pendipa.v3i1.6926

\begin{abstract}
[Identification of Soil Response to Earthquake Waves in Curup and its Implementation on Physics Learning]. Scientific research has been conducted in the Curup in five districts namely Selupu Rejang, center Curup, eastern Curup, southern Curup and Curup city. Curup city is a mountainous area located in the earthquake belt. The aim of research was to determine the level of vulnerability of land in the Curup city and to explain the difference in student learning outcomes XI IPA 1 and XI IPA 2 after participating in learning by using learning model Problem Based Learning $(P B L)$ and Conventional Methods on the material elasticity. Seismic susceptibility index data values obtained from field research using HVSR microseismic tools. Data management using DATAPRO software and GEOPSY software. The result of the highest level of susceptibility to the soil is 4.18 and is located at the maximum temperature of the soil. The results of educational research show that there are differences in student learning outcomes taught with PBL learning models and conventional methods. The experimental class learning outcomes have an average value of 80.70, while the control class has an average value of 73.20 .
\end{abstract}

Keywords: Vulnerability; earthquake; PBL model.

(Received August 14, 2018; Accepted January 10, 2019; Published February 27, 2019)

\begin{abstract}
ABSTRAK
Penelitian sains telah dilakukan di Daerah Curup di lima kecamatan yaitu Selupu Rejang, Curup Tengah, Curup Timur, Curup Selatan dan Curup Kota pada tanggal 07 Agustus 2016. Kota Curup merupakan daerah pegunungan yang terletak pada jalur gempa. Tujuan penelitian untuk mengetahui tingkat kerentanan tanah di kota Curup dan Untuk menjelaskan Perbedaan hasil belajar siswa kelas XI IPA 1 dan XI IPA 2 setelah mengikuti pembelajaran dengan menggunakan model pembelajaran Problem Based Learning (PBL) dan Metode Konvensional pada materi elastisitas. Data nilai indeks kerentanan seismik diperoleh dari penelitian lapangan dengan menggunakan alat mikroseismik HVSR. Pengelolahah data menggunakan software DATAPRO dan software GEOPSY. Hasil tingkat kerentanan tanah tertinggi mencapai 4,18 dan terletak pada kecamatan Selupu Rejang. Hasil penelitian pendidikan menunjukkan terdapat perbedaan hasil belajar siswa yang diajarkan dengan model pembelajaran PBL dan metode konvensional. Hasil belajar kelas eksperimen memiliki nilai rata-rata 80,70, sedangkan kelas kontrol memiliki nilai rata-rata 73,20.
\end{abstract}

Kata kunci: Kerentanan; gempa bumi; model PBL.

\section{PENDAHULUAN}

Gempa bumi adalah hasil dari pelepasan energi secara tiba-tiba dalam kerak bumi yang menghasilkan gelombang seismik (Pulinets,
2004). Dampak yang ditunjukkan akibat gempa bumi yang terjadi di suatu daerah sangat bergantung pada jenis, jarak, kekuatan dan lamanya gempa bumi tersebut. Gempa 
bumi diukur dengan sebuah seismometer, sebuah perangkat yang juga dikenal sebagai catatan seismograf. Intensitas getaran gempa bumi diukur pada skala Mercalli (Susanto, 2011). Kedalaman gempabumi akan berpengaruh pada kerusakan yang disebabkannya, semakin dangkal gempa bumi, kerusakan yang disebabkannya akan besar pula (Spence dkk, 1999).

Propinsi Bengkulu merupakan daerah pegunungan aktif dan daerah lempeng tektonik. Letak propinsi Bengkulu di pulau Sumatra dipengaruhi oleh Zona patahan Semangko merupakan jalur patahan yang terbentuk akibat tabrakan Lempeng IndoAustralia yang bergerak dengan kecepatan relatif 50 hingga $60 \mathrm{~mm} /$ tahun terhadap lempeng Eurasia yang relatif diam. Keberadaan patahan ini juga berpotensi untuk menyebabkan sejumlah gempa bumi dangkal yang bersifat merusak. Selain itu,wilayah Kabupaten Rejang Lebong, khususnya wilayah bagian Barat, yang berada pada jalur Sistem Sesar Sumatera (Sesar Ketaun dan Sesar Musikeruh yang merupakan jalur patahan utama) yang merupakan daerah rawan gempa. Data BMKG pada tahun 1979 kabupaten Rejang Lebong pernah terjadi gempa bumi yang sangat kuat. Sehingga mengakibatkan banyak korban jiwa dan rusaknya bangunan.

Secara umum kondisi fisik Kabupaten Rejang Lebong sebagai berikut: Kelerengan: datar sampai bergelombang, Jenis Tanah: Andosol, Regosol, Podsolik, Latasol dan Alluvial, Tekstur Tanah: sedang, lempung dan sedikit berpasir dengan $\mathrm{pH}$ tanah 4,5 -7,5. Kedalaman efektif tanah sebagian besar terdiri atas kedalaman $60 \mathrm{~cm}$ hingga lebih dari $90 \mathrm{~cm}$, sebagian terdapat erosi ringan dengan tingkat pengikisan $0-10 \%$. Secara topografi, Kabupaten Rejang Lebong merupakan daerah yang berbukit-bukit, terletak pada dataran tinggi pegunungan Bukit Barisan dengan ketinggian $100>1000 \mathrm{~m}$ dpl.

Resiko-resiko yang disebabkan oleh terjadinya gempa bumi bukan hanya resiko terjadi pada kegagalan struktur bangunan saja, namun juga resiko kegagalan yang terjadi pada struktur tanah yang mendukung bangunan di atasnya. Kerusakan-kerusakan pada struktur tanah (Bella, dkk. 2015) diantaranya terjadi penurunan tanah (settlement), jatuhan batuan (rock fall), tanah longsor dan kerusakan yang berhubungan dengan keseimbangan lereng (land slide dan slope stability) dan likuifaksi (liquefaction). Respon batuan terhadap getaran gelombang seismik yang melewatinya akan berbeda beda, tergantung pada jenis batuan. Karakter respon batuan tersebut dapat menunjukkan spesifik dari jenis suatu batuan. Menurut Gurler dkk. (2000) memberikan informasi secara empiris, bahwa antara satu tempat dengan tempat yang lain memiliki karakteristik dinamik tanah yang berbeda beda. Salah satu upaya untuk mengatasi atau mengurangi resiko gempa bumi agar dampaknya tidak begitu besar dapat dilakukan pengkajian pemeriksaan kerapatan tanah dengan melakukan penelitian menggunakan seperangkat sismometer portable short tipe 3 komponen. Dengan mengetahui kerapatan tanah suatu tempat maka kita bisa mengetahui daerah mana yang bisa didirikan bangunan.

Daerah Curup Kabupaten Rejang Lebong merupakan daerah pegunungan dan merupakan jalur gempa. Maka dari itu penelitian ini dilakukan di Curup untuk mengetahui tingkat kerentanan tanah jika terjadi gempa. Ilmu Pengetahuan Alam (IPA) berkaitan dengan cara mencari tahu tentang fenomena alam secara sistematis, sehingga IPA bukan hanya penguasaan kumpulan pengetahuan yang berupa fakta-fakta, konsepkonsep, atau prinsip-prinsip saja tetapi juga merupakan suatu proses penemuan. Pembelajaran IPA diharapkan dapat membantu siswa dalam memecahkan suatu masalah. Proses pembelajaran IPA ini dapat dilakukan langsung di lapangan atau di laboratorium. Fisika merupakan cabang dari ilmu IPA yang mempelajari sifat dan fenomena alam atau gejala alam serta seluruh interaksi yang ada di dalamnya (Adisendjaja, 2008). Di dalam mempelajari fenomena atau gejala alam, fisika menggunakan proses yang terdiri atas pengamatan, pengukuran, analisis, dan penarikan kesimpulan.

Hasil observasi di SMAN 1 Selupu Rejang guru jarang sekali menggunakan alat peraga untuk mengajar. Sehingga ini menyebabkan siswa menjadi bosan. Hal ini dapat dilihat dari kurangnya minat siswa dalam bertanya dan menjawab pertanyaan dari guru.

Salah satu model pembelajaran yang dapat digunakan dalam pembelajaran fisika yaitu model pembelajaran berbasis masalah (Problem Based Learning). Model ini pembelajaran ini menyajikan masalah nyata yang penyelesaiannya membutuhkan kerja 
sama siswa, dan guru memandu siswa untuk menguraikan rencana pemecahan masalah menjadi tahap-tahap kegiatan. Menurut Gallagher dalam Ngalimun (2015) model pembelajaran PBL merupakan model berbasis masalah yang penyelesaiannya dapat dilakukan bersama sama dengan menggunakan metode eksperimen. Penelitian pembelajaran menggunakan model PBL juga pernah dilakukan oleh Susilawati dkk (2017) dan didapatkan hasil penelitian bahwa terdapat peningkatan hasil belajar pada konsep Perpindahan Kalor siswa kelas X-TKJ SMK Negeri 1 Bengkulu Tengah menggunakan model PBL.

Berdasarkan hasil observasi di SMAN 1 Selupu Rejang kelas XI, model pembelajaran fisika yang digunakan guru dalam mengajar kurang bervariasi. Padahal di sekolah telah tersedia media yang menunjang untuk pelajaran fisika seperti KIT atau alat pratikum. Alasan guru jarang menggunakan KIT atau alat pratikum karena banyak membutuhkan waktu, sedangkan waktu yang diberikan pada pelajaran fisika sangat terbatas. Hal ini dapat dilihat dari kurangnya minat siswa dalam bertanya dan menjawab pertanyaan dari guru. Maka dari itu penelitian ini bertujuan untuk menjelaskan perbedaan hasil belajar siswa menggunakan model pembelajaran PBL dan metode konvensional.

\section{METODE PENELITIAN}

Adapun tahapan yang dilaksanakan dalam penelitian ini dilakukan penelitian sains penelitian pendidikan.

\section{Penelitian Sains}

Penelitian ini merupakan penelitian lapangan. Penelitian lapangan berupa akuisi data untuk mendapat nilai indeks kerentanan seismik pada titik-titik lokasi yang telah ditetapkan secara zonasi di daerah Curup yaitu pada5 kecamatan tepatnya di kecamatan selupu rejang, curup timur, curup selatan, curup tengah dan curup kota dengan 6 titik koordinat.

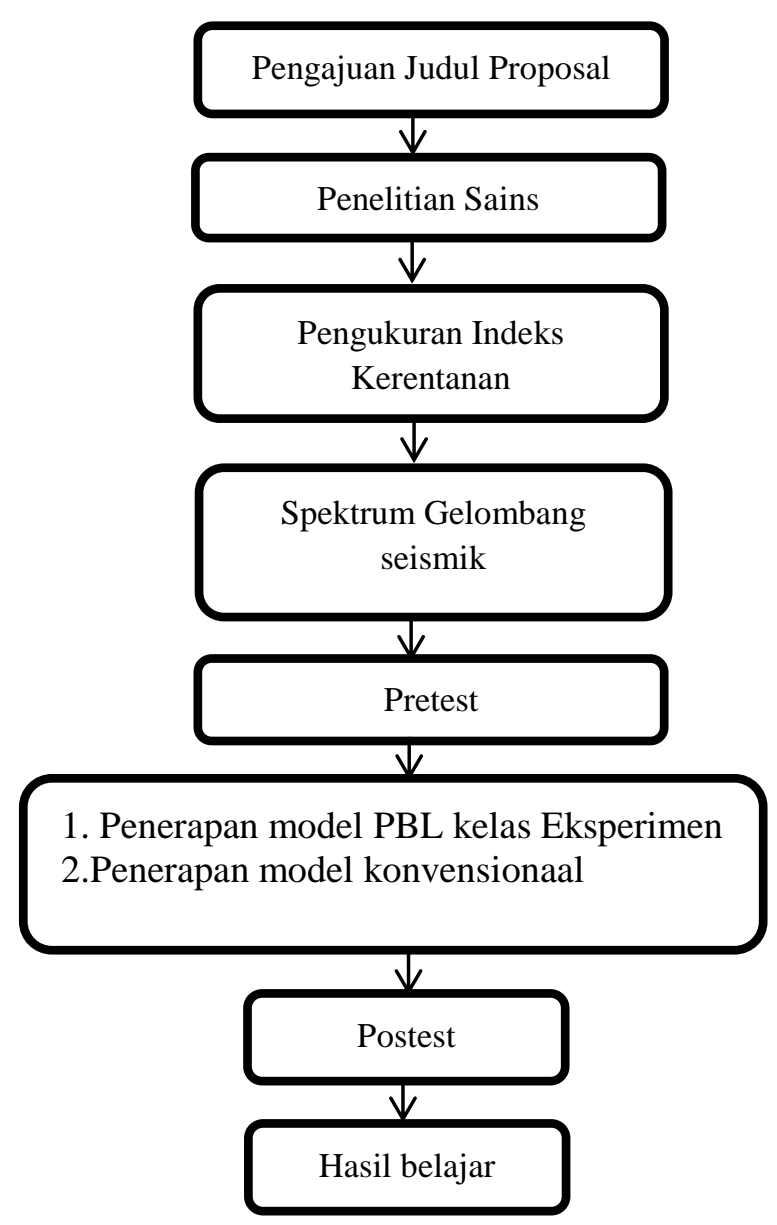

Gambar 1. Tahapan penelitian pendidikan

Pada penelitian ini alat-alat yang dibutuhkan telah tersedia di laboratorium MIPA UNIB. Alat-alat yang digunakan untuk penelitian sains antara lain:

1. Seperangkat sismometer portable short periode tipe 3 komponen

2. Global Position system (GPS) portable, digunakan untuk memberikan informasi lintang dan bujur titik penelitian

3. Software pengelola yaitu data pro, geopsy, dan surfer versi 9

4. Laptop

5. Kamera digital dan Tab 4 samsung

\section{Penelitian Pendidikan}

Penelitian ini dilaksanakan di kelas XI di SMAN 1 Selupu Rejang pada bulan September Tahun Pelajaran 2016/2017 pada pokok bahasan elastisitas bahan. Dengan populasi penelitian seluruh kelas XI di SMAN 1 Selupu Rejang semester I tahun pelajaran 2016/2017

Prosedur Penelitian Sains 
Adapun prosedur penelitian yang akan dilaksanakan sebagai berikut :

1. Menyiapkan alat yang di gunakan yaitu mikroseismik, GPS, laptop, kompas. dipastikan semua alat bekerja dengan baik.

2. Penentuan lokasi penelitian

3. Dilakukan uji coba, revisi dan kalibrasi alat

4. Mencatat koordinat yang terbaca oleh GPS,

5. Menggunakan kompas,

6. Mengatur posisi mikroseismik 1 sensor (1 geophone) sesuai arah utara yang ditunjukan pada kompas,

7. Mengatur posisi mikroseismik 1 sensor (1 geophone) secara datar dengan tanah, ditunjukan oleh letak posisi tengah,

8. Menghubungkan sensor dengan laptop menggunakan kabel data,

9. Mengatur sample rate dan aquisision length sesuai dengan yang kita inginkan (disini peneliti menggunakan sample rate $10 \mathrm{~ms}(100 \mathrm{~Hz})$ dan aquisision length 30menit (180.000 samples)),

10. Merekam data (record),

11. Setelah selesai merekam data lalu simpan data dalam bentuk SAV.

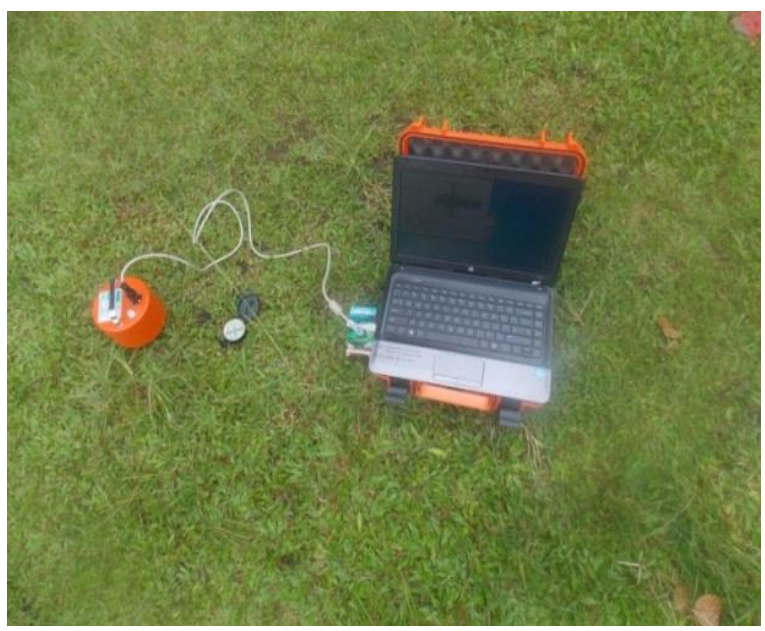

Gambar 2. Peralatan yang digunakan dalam penelitian sains

\section{Prosedur Penelitian Pendidikan}

Adapun tahapan penelitian ini adalah :

\section{Tahap Perencanaan}

1. Penyiapan perangkat pembelajaran yang menggunakan model pembelajaran Problem Based Learning dan metode konvensional

\section{Penyiapan instrumen tes}

\section{Tahap Pelaksanaan}

Tahap pelaksanaan antara lain: 1) pembelajaran dilaksanakan sesuai jam pembelajaran yang telah ditentukan, 2) proses pembelajaran menggunakan model pembelajaran Problem Based Learning di kelas eksperimen, dan 3) proses pembelajaran menggunakan metode konvensional di kelas kontrol.

\section{Hasil belajar siswa}

Untuk mengetahui hasil belajar siswa yang mengikuti pembelajaran menggunakan model pembelajaran Problem Based Learning dan hasil Belajar siswa yang mengikuti pembelajaran metode konvensional maka diadakan evaluasi.

\section{Teknik dan Analisa Data Sains}

Teknik pengumpulan data yaitu dengan memasang alat mikrosesmik 1 sensor (geophone) pada titik yang sudah ditentukan. Hubungkan semua alat seperti seismometer mikrosesmik 1 sensor (geophone) dengan laptop, lalu atur sampel rate dengan menggunakan $10 \mathrm{~ms}(100 \mathrm{~Hz})$ dan aquisision lenght tunggu dalam jangka waktu lebih kurang 30 menit untuk memperoleh hasil 180.000 sampel . Data yang diperoleh akan ditampilkan langsung ke laptop masih berupa data mentah.

Data diperoleh secara langsung dengan memasang alat sesuai titik koordinat yang sudah ditentukan. Setelah data diperoleh maka akan analisis dengan persamaan:

$$
K_{g}=A^{2} / f_{o}
$$

Keterangan : $\mathrm{K}_{\mathrm{g}}=$ indeks kerentana seismik

$$
\mathrm{A}^{2}=\text { faktor amplifikasi }
$$

$\mathrm{f}_{\mathrm{o}}=$ frekuensi resonsansi

\section{Teknik dan Analisa Data Pendidikan}

Pengolahan dan analisis data dalam penelitian ini dilakukan terhadap skor pretes dan skor posttes siswa dalam tes aspek kognitif. Pengolahan dan analisis data yang dilakukan meliputi analisis deskriptif, analisis inferensial dan pengujian hipotesis. 
Menurut Sugiyono (2009) analisis deskriptif digunakan untuk menganalisis data dengan cara mendiskripsikan atau menggambarkan data yang telah terkumpul sebagaimana adanya tanpa bermaksud membuat kesimpulan yang berlaku untuk umum atau generalisasi. Termasuk dalam analisis deskriptif antara lain adalah penyajian data melalui tabel, grafik, perhitungan range, skor minimum, skor maksimum skor rata- rata (mean), varian, standar deviasi, dan $\mathrm{N}$-gain .

Menghitung Mean

Menurut Sudjana (1996) rumus yang digunakan untuk menghitung mean adalah:

$$
\overline{\mathrm{x}}=\frac{\sum x i}{n}
$$

Keterangan :

$\sum x i=$ jumlah semua nilai ujian yang ada dalam kumpulan,

$\mathrm{n} \quad=$ jumlah siswa yang mengikuti ujian

$\bar{x} \quad=$ rata-rata nilai.

\section{Perhitungan Gain dan $N_{\text {-gain }}$}

Gain adalah selisih nilai pretes dan posttest antara kelas ekprimen dengan kelas kontrol. Untuk mengetahui peningkatan hasil belajar siswa antara yang menggunakan model PBL dengan model pembelajaran konvensional antara sebelum dan sesudah dilakukan perhitungan gain ternormalisasi $(N$ gain).

$$
N-\text { gain }=\frac{\text { Spost }- \text { Spret }}{S \max -\text { Spre }}
$$

\section{HASIL DAN PEMBAHASAN}

\section{Hasil Dan Pembahasan Penelitian Sains}

Penelitian ini bertujuan untuk mengetahui tingkat kerentanan tanah di daerah Curup jika terjadi gempa bumi dengan melihat indek kerentanan sismik.

\begin{tabular}{|c|c|c|c|c|c|}
\hline Ordinat $\mathrm{S}$ & Ordinat $\mathrm{E}$ & $\left(f_{o}\right)$ & (A) & $\mathrm{A}^{\wedge} 2$ & $\overline{K_{g}}$ \\
\hline $\begin{array}{l}03^{\circ} 27^{\prime} 09, \\
8^{\prime \prime}\end{array}$ & $\begin{array}{l}102^{03} 38^{\prime} 39 \\
9^{\prime \prime}\end{array}$ & 4,2 & 4,19 & $\begin{array}{l}17,5 \\
5\end{array}$ & 4,18 \\
\hline $\begin{array}{l}03^{\circ} 28^{\prime} 13, \\
1^{\prime \prime}\end{array}$ & $\begin{array}{l}102^{0} 34 ’ 49 \\
, 1 "\end{array}$ & 2,43 & 3,32 & 5,38 & 2,21 \\
\hline $\begin{array}{l}03^{\circ} 27^{\prime} 24, \\
4^{\prime \prime}\end{array}$ & $\begin{array}{l}102^{03} 33^{\prime} 13 \\
, 8^{\prime \prime}\end{array}$ & 3,64 & 2,23 & 4,88 & 1,34 \\
\hline $\begin{array}{l}03^{\circ} 29^{\prime} 32, \\
5^{\prime \prime}\end{array}$ & $\begin{array}{l}102^{0} 31 ’ 29 \\
, 1{ }^{\prime \prime}\end{array}$ & $\begin{array}{l}11,6 \\
6\end{array}$ & 3,13 & 9,79 & 0,84 \\
\hline
\end{tabular}

Tabel 1. Nilai Indeks Kerentanan seismik

\begin{tabular}{|c|c|c|c|c|c|}
\hline $\begin{array}{l}03^{\circ} 29^{\prime} 10, \\
0^{\prime \prime}\end{array}$ & $\begin{array}{l}102^{0} 31^{\prime} 10 \\
1 " \prime\end{array}$ & 2,26 & 1,5 & 2,25 & 0,99 \\
\hline 0 & 10 & & 2,18 & 4,75 & 1,05 \\
\hline $\begin{array}{l}3^{0} 26^{\prime} 09,8 \\
"\end{array}$ & $\begin{array}{l}2^{0} 32^{\prime} 39,9 \\
״\end{array}$ & ,52 & & & \\
\hline
\end{tabular}

Tabel 1 menunjukkan bahwa dapat dilihat besar kecilnya tingkat kerentanan di setiap titik lokasi di daerah Curup melalui nilai indeks kerentanan seismik $\left(K_{g}\right)$. Di daerah Curup terwakili oleh enam titik yang diambil, meliputi 5 kecamatan di daerah Curup.

Data yang telah diperoleh harus diolah menggunakan software DATAPRO untuk mengubah data dalam format ASCII. Data dalam format ASCII selanjutnya diubah dalam format SAF (sesame ASCII Format) dengan menggunakan software GEOPSY. Selanjutnya data dapat dilihat dalam bentuk spekrum gelombang seperti Gambar 2.

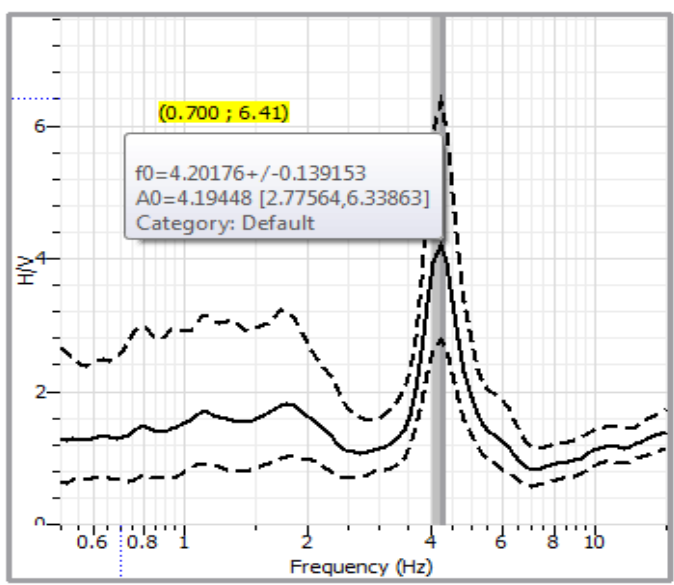

Gambar 2. Spektrum gelombang berdasarkan hasil HVSR

Gambar 2 menunjukkan spektrum gelombang, berdasarkan hasil HVSR menghasilkan spektrum mikrosesmikdengan puncak spektrum pada frekuensi resonansinya. Frekuensi resonansi $\left(f_{o}\right)$ dan faktor amplifikasi (A) merupakan parameter yang mencerminkan karakteristik dinamik lapisan tanah permukaan (Nakamura dkk., 2000). Selain itu dengan mengetahui frekuensi resonansi $\left(f_{o}\right)$ dan faktor amplifikasi (A) dapat diketahui indeks kerentanan seismik $\left(K_{g}\right)$. Indeks kerentanan seismic $\left(K_{g}\right)$ merupakan indeks yang menunjukan tingkat kerentanan suatu lapiasan tanah yang mengalami deformasi. Oleh karenanya indeks ini berguna untuk mendeteksi daerah yang merupakan zona lemah (uncoslidated sediment) pada saat ini terjadi gempa. 
Kerentanan seimik ditentukan oleh nilai indeks kerentanan seismik $\left(K_{g}\right)$ yang menggambarkan tingkat kerentanan lapisan tanah permukaan terhadap deformasi saat terjadi gempa bumi. Indeks kerentanan seismik berkaitan dengan kondisi geomorfologis.

Dari data nilai indeks kerentanan di atas, dapat diketahui tingkat kerentanan di daerah Curup saat terjadi gempa bumi. Tingkat kerentanan dapat dikatakan dalam kategori rendah. Karena nilai indeks kerentanan tanahnya cukup kecil dibawah 2 . Tetapi ada 2 titik koordinat yang memiliki tingkat kerentana dalam kategori sedang, ini semua dapat dilihat dari nilai indeks yaitu 2,21 dan 4,18.

Perbedaan nilai indeks kerentanan seismik ini disebabkan karena adanya perbedaan struktur lapisan tanah. Jika lapian tanah atau tingkat kerapatan tanahnya padat maka nilai indeks kerntanan tanahnya kecil. Sebaliknya jika lapisan tanah atau tingkat kerapatan tanahnya tidk begitu padat maka nilai indeks kerentanan tanahnya besar. Penelitian yang dilakukan oleh Gurler dkk. (2000) di Mexico City menemukan fakta bahwa indeks kerentanan seismik tinggi tersebar di zona bekas rawa dan daerah reklamasi, sedangkan di daerah transisi (antara dataran aluvial dan perbukitan).Di daerah Curup memiliki jenis tanah andosol, regosol, latosol dan alluvial. Inilah yang menyebabkan nilai indeks kerentanan di daerah Curup berbeda.

\section{Hasil dan Pembahasan Penelitian Pendidikan}

Hasil belajar adalah kemampuan yang dimiliki siswa setelah ia menerima pengalaman belajarnya (Nurdyansyah dan Fitriyani, 2018). Hasil belajar mempunyai peranan penting dalam proses pembelajaran. Proses penilaian terhadap hasil belajar dapat memberikan informasi kepada guru tentang kemajuan siswa dalam upaya mencapai tujuantujuan belajarnya melalui kegiatan belajar.

Hasil belajar adalah ukuran atau tingkat keberhasilan yang dapat dicapai oleh seorang siswa berdasarkan pengalaman yang diperoleh setelah dilakukan evaluasi berupa tes dan biasanya diwujudkan dengan nilaiatau angkaangka tertentu sertamenyebabkan terjadinya perubahankognitif, afektif, maupun psikomotorik (Sudjana, 1996)

Pada penelitian ini untuk melihat perbedaan hasil belajar guru menggunakan model pemebelajaran PBL yang dibandingkan dengan metode konvensional. Problem Based Learning (PBL) merupakan model pembelajaran yang berorientasi pada kerangka kerja teoritik konstruktivisme. Dalam model pembelajaran PBL, fokus pembelajaran ada pada masalah yang dipilih sehingga pembelajaran tidak saja mempelajari konsepkonsep yang berhubungan dengan masalah tetapi juga metode ilmiah untuk memecahkan masalah tersebut.

Karakteristik-karakteristik PBL sebagai berikut: (1) belajar dimulai dengan suatu masalah, (2) memastikan bahwa masalah yang diberikan berhubungan dengan dunia nyata siswa, (3) mengorganisasikan pembelajaran diseputar masalah, bukan disekitar disiplin ilmu, (4) memberikan tanggung jawab yang besar kepada pebelajar dalam membentuk dan menjalankan secara langsung proses belajar mereka sendiri, (5) menggunakan kelompok kecil, dan (6) menuntut pebelajar untuk mendemonstrasikan apa yang telah mereka pelajari dalam bentuk suatu suatu produk atau kinerja.

Tabel 2. Nilai rata-rata siswa pretes dan postes

\begin{tabular}{|l|l|l|l|}
\hline \multicolumn{1}{|c|}{ Kelas } & \multicolumn{3}{|c|}{ Mean } \\
\cline { 2 - 4 } & Pretes & Posttes & N-gain \\
\hline Eksperimen & 39,73 & 80,70 & 0,68 \\
\hline Kontrol & 40,53 & 73,20 & 0,55 \\
\hline
\end{tabular}

Sintak model pembelajaran PBL sebagai berikut: (1) Orientasi siswa pada masalah, (2) Mengorganisasi siswa untuk belajar, (3) Membimbing penyelidikan individual maupun kelompok, (4) Mengembangkan dan menyajikan hasil karya, (5) Menganalisis dan mengevaluasi proses pemecahan masalah.

Berdasarkan Tabel 2 nilai rata-rata pretest pada kontrol adalah 40,53 yang diperoleh dari 30 siswa. Sedangkan nilai ratarata pretest kelas eksperimen adalah 39,73 diperoleh dari 30 siswa. Tetapi setelah diberikan perlakuan terhadap kelas eksperimen menggunakan model PBL dan kelas kontrol menggunakan metode konvensional, nilai skor rata-rata posttest kelas eksperimen lebih tinggi dibandingkan kelas kontrol. Nilai rata-rata posttest kelas kontrol 73,20 dan nilai rata-rata posttest kelas eksperimen 80,70. Setelah dilakukan uji kesamaan dua rata-rata dengan 
menggunakan uji-t diperoleh hasil, skor ratarata posttest kelas eksperimen berbeda secara signifikan dengan skor rata-rata posttest ratarata kelas kontrol dengan $t_{\text {hitung }} 3,732>t_{\text {tabel }}$ 1,997 untuk taraf signifikan $95 \%$.

Hasil penelitian kelas eksperimen menunjukkan bahwa penerapan model pembelajaran Problem based learning (PBL) pada pelajaran fisika di SMAN 1 Selupu Rejang dapat meningkatkan hasil belajar siswa. Hasil belajar tersebut adalah hasil belajar pada aspek kognitif. Adapun besar perbedaan peningkatan hasil belajar fisika siswa antara kelas eksperimen dan kelas kontrol adalah $13 \%$. Hasil tersebut di dapat dari pengurangan nilai $\mathrm{N}$-gain pada kelas eksperimen dan kelas kontrol yakni 0,68 atau $68 \%$ kelas eksperimen dan 0,55 atau $55 \%$ kelas kontrol .

Perbedaan hasil belajar kognitif antara siswa yang belajar fisika menggunakan model pembelajar Problem Based Learning (PBL) dan siswa yang belajar fisika menggunakan metode konvensional dipengaruhi oleh beberapa faktor, diantaranya metode pembelajaran yang diterapkan oleh guru. Maka dari itu guru harus bisa memilih metode yang tepat untuk menyampaikan materi agar tujuan pembelajaran dapat tercapai.

Metode konvensional yang diterapkan pada kelas kontrol adalah metode ceramah dan latihan soal. Proses pembelajaran dengan metode konvensional berbeda dengan proses pembelajaran dengan menggunakan model pembelajaran Problem Based Learning. Pada awal pelajaran guru melakukan apersepsi untuk memberikan gambaran tentang materi yang akan disampaikan. Kemudian guru mulai menjelaskan materi elastisitas bahan kepada siswa sambil membimbing siswa melakukan tanya jawab. Selanjutnya guru memberikan soal kepada siswa dan menjawabnya secara bersama-sama. Lalu guru memberikan soal latihan dan diminta siswa untuk mengerjakan soal latihan. Selanjutnya diminta beberapa siswa untuk menuliskan jawabannya dipapan tulis dan dibahas secara bersama-sama. Selama kegiatan belajar berlangsung tidak ada perlakuan lain yang diberikan didalam kelas.

Model pembelajaran Problem Based Learning (PBL) merupakan model pembelajaran yang mengorientasikan siswa pada masalah. Pembelajaran menggunakan model PBL ini menuntut siswa untuk dapat terampil dalam menyelesaikan masalah dengan kerja sama. Pada pembelajaran PBL dapat menguntungkan bagi siswa berprestasi rendah maupun tinggi yang mengerjakan tugas akademik bersama-sama. Mereka yang berprestasi tinggi mengajari teman-temannya yang berprestasi lebih rendah, sehingga memberikan bantuan khusus dari sesama teman. Sementara mereka yang berprestasi tinggi juga memperoleh hasil secara akademik karena bertindak sebagai tutor yang dituntut untuk berfikir lebih mendalam tentang hubungan di antara berbagai ide dalam subyek tertentu.

Pada awal kegiatan pembelajaran berlangsung melakukan apersepsi untuk memberikan gambaran materi kepada siswa. selanjutnya guru mulai mengoriantasikan siswa pada masalah dan diminta siswa untuk mencermati masalah pada materi. Selanjutnya guru mengoganisasikan siswa untuk belajar dengan membentuk kelompok. Kemudian siswa diminta untuk melakukan percobaan dengan mengguanakn panduan LKS yang telah diberikan. Ketika siswa melakukan percobaan peran guru disini membimbing siswa saat melakukan percobaan. Setelah siswa selesai melakukan percobaan diminta untuk menjawab soal pada LKS dan membuat kesimpulan hasil dari percobaan. Selanjutnya diminta beberapa kelompok untuk menyampaikan hasil kerja mereka. Dan diminta kelompok lain untuk memperhatikan sekaligus mengevaluasi hasil kerja temannya bersama guru.

\section{KESIMPULAN}

Tingkat kerentanan tanah di daerah Curup dapat dikategorikan rendah. Karena nilai rata-rata indeks kerentanan 2. Dari enam titik pengambilan data, 2 titik dalam kategori sedang dengan nilai indeks lebih dari 2 . Sedangkan 4 titik dalam kategori kategori rendah dengan nilai indeks kurang dari 2 . Perbedaan nilai indeks kerentanan ini dipengaruhi beberapa faktor seperti pembentukan lahan, jenis batuan dan lapisan tanah atau kerapatan tanah. Semakin baik kerapatan tanah semakin rendah indeks kerentanannya. Sebaliknya semakin buruk tingkat kerapatan tanah maka semakin tinggi tingkat kerentanan tanahnya. Terdapat perbedaan hasil belajar fisika antara model pembelajaran Problem based learning (PBL) dengan metode konvensional (ceramah dan latihan soal) di SMAN 1 Selupu Rejang. 
Perbedaan ini dapat dilihat dari nilai rata-rata posttes pada kelas eksperimen dan kelas kontrol. Pada kelas eksperimen nilai rata-rata postest adalah 80,70 sedangkan pada kelas kontrol nilai rata-rata postest 73,20.

\section{DAFTAR PUSTAKA}

Adisendjaja, Y. H. (2008). Analisis Buku Ajar Biologi SMA Kelas X di Kota Bandung Berdasarkan Literasi Sains. Bandung: Jurusan Pendidikan Biologi, FMIPA Universitas Pendidikan Indonesia

Bella, R. A., Bunganaen, W., \& Sogen, P. M. (2015). Identifikasi Kerusakan Konstruksi Akibat Potensi Pengembangan Tanah Lempung Ekspansif Di Desa Oebelo. Jurnal Teknik Sipil, 4(2), 195-208

Gurler, E. D., Nakamura, Y., Saita, J., \& Sato, T. (2000). Local site effect of Mexico City based on microtremor measurement. In 6th International Conference on Seismic Zonation. Palm Spring Riviera Resort, California, USA (p. 65).

Ngalimun. (2014). Strategi dan Model Pembelajaran. Yogyakarta: Aswaja Presindo.

Nurdyansyah, N., \& Fitriyani, T. (2018). Pengaruh Strategi Pembelajaran Aktif Terhadap Hasil Belajar Pada Madrasah
Ibtidaiyah. Universitas Muhammadiyah Sidoarjo

Pulinets, S. (2004). Ionospheric precursors of earthquakes; recent advances in theory and practical applications. Terrestrial Atmospheric and Oceanic Sciences, 15(3), 413-436.

Spence, W., Mendoza, C., Engdahl, E. R., Choy, G. L., \& Norabuena, E. (1999). Seismic subduction of the Nazca Ridge as shown by the 1996-97 Peru earthquakes. In Seismogenic and Tsunamigenic Processes in Shallow Subduction Zones (pp. 753-776). Birkhäuser, Basel.

Sudjana. (1996). Metode Statistik. Bandung: Tratisto.

Sugiyono. (2009). Metode Penelitian. Bandung: Alfabeta.

Susilawati, Z., Mayub, A., \& Farid, M. (2018). Menghitung nilai emisivitas warna menggunakan miniatur ruang berbentuk silinder sebagai media pembelajaran fisika. PendIPA Journal of Science Education, 2(2).

Susanto, A. (2011). Perhitungan Percepatan Tanah Maksimum Berdasarkan Data Gempa Bumi di Daerah Istimewa Yogyakarta (Doctoral dissertation, Universitas Negeri Semarang). 